\title{
Techno-economic analysis of solar photovoltaic based submersible water pumping system for rural areas of an Indian state Rajasthan
}

\author{
Shiv Lal ${ }^{1, *}$, Pawan Kumar ${ }^{2}$, Rajeev Rajora ${ }^{2}$ \\ ${ }^{1}$ Centre for Energy Studies, Indian Institite of Technology Delhi, India \\ ${ }^{2}$ Department of Mechanical Engineering, Rajasthan Technical University Kota, India
}

Email address:

Shivlal1@gmail.com (S. Lal),pawan4978@gmail.com (P. Kumar), rrajora@yahoo.com (R. Rajora)

\section{To cite this article:}

Shiv Lal, Pawan Kumar, Rajeev Rajora. Techno-Economic Analysis of Solar Photovoltaic Based Submersible Water Pumping System for Rural Areas of an Indian State Rajasthan . Science Journal of Energy Engineering . Vol. 1, No. 1, 2013, pp. 1-4.

doi: 10.11648/j.sjee.20130101.11

\begin{abstract}
The utilization of solar energy to generate the off-grid electric power is a prominent technology which is utilized in photovoltaic based water pumping system for agriculture and community water supply in this stud. It helps to improve the agricultural productivity which improves the living standard of a farmer and also reduces the $\mathrm{CO}_{2}$ emissions by replacing fossil fuels. This technology replaces $100 \%$ fossil fuel system and save $\mathrm{CO}_{2}$ by $14977.57 \mathrm{~kg} /$ year. This paper presents fuel replacement and reduction of carbon dioxide on an annual basis and economic analysis of photovoltaic based water pumping system.
\end{abstract}

Keywords: Net Present Value, Payback Period, Financial Indicator, $\mathrm{CO}_{2}$ Mitigation and Energy Conservation

\section{Introduction}

In developing countries, water pumping energy requirement is meeting out through conventional power. And the conventional power is supplied for a limited period of the day, In Rajasthan it is 6-8 hour per day. This duration is not sufficient for agriculture and diesel water pumping system would be used but its operation is costly because of high diesel fuel cost. Many researchers worked on the sustainable energy consumption, renewable energy sources, energy efficiency in developing countries [1, 2-3, 4-5]. The water pumping with solar energy is a promising option to conserve the natural resources of energy. The clear sky day approximates 300-325 days observed in Kota district of Rajasthan state.

To grow the product where the grid energy doesn't reach in the hands the PV system plays important role in developing countries like India. Another important reason of using PV based pumping systems is: conventional electricity not supplied in sufficient time (6-8 hour supplied to farmers in Rajasthan India), the cost of conventional energy, government subsidy in solar pumping systems and it is difficult to extend the electric grid to every location where it is needed for every farmer.
Therefore the factors affect to lead down the use of diesel engine [1]. The cost of conventional fuel increasing day by day and the operating cost of a diesel engine will be increasing. Due to the high fuel cost, operating the PV system above $7.2 \mathrm{~kW}$ is feasible and having less operating cost than a diesel engine. The decentralized system is feasible where the population is living at a small bunch in the far distance [6]. Many countries are adopting the decentralized grid system to supply the electricity in rural areas [7].

Purohit [8] studied the financial evaluation of renewable energy technologies for water pumping in India. A simple framework developed and unit cost of water and unit cost of useful renewable energy have been estimated. Odeh et al. [9] studied on the economic viability of a photovoltaic water pumping systems, it compared with the diesel engine pumping system and found it is a viable option for off-grid water pumping.

There is a very little study available on cost economics of photovoltaic based water pumping system. Keeping this in view an attempt has been made to evaluate the techno-economics of photovoltaic (PV) based water pumping system particularly for Indian state Rajasthan.

\section{Methodology}


The more than 300 clear sky days observed throughout the year in Kota district of Rajasthan state. To keep in mind solar energy has been measured and it is found sufficient to run the PV based submersible pump in winter also. The economic assessment of PV based water pumping system is adopted from Panwar et al. [5] and Kandpal \& Garg [10]. The net present value and payback period has been evaluated for economic assessment.

The following assumption was made for economic analysis,

Interest rate (i) $10 \%$

Repair and maintenance (AM) is $5 \%$ of the capital cost of PV based water pumping system

Life span (n) 20 year

The net present value of the system can be calculated by,

$$
N P V=-I C+(A S-A M)\left[\frac{(1+i)^{n}-1}{i(1+i)^{n}}\right]
$$

Where, $\mathrm{IC}=$ Initial cost, $\mathrm{AS}=$ Annual saving and $\mathrm{AM}=$ Annual maintenance

And the payback period (PP) can be calculated by

$$
P P=\frac{I C}{A S-A M}
$$

For the calculation of NPV and PP we have taken the initial cost of the three systems PV, Diesel and compressed natural gas (CNG) as Rs. 85000.00, 70000.00 and 100000.00 respectively and selected diesel and CNG engine of $5.884 \mathrm{~kW}$ used for the equivalent discharge and calculated running time is being $1447.43 \mathrm{hr}$. The present diesel and $\mathrm{CNG}$ price we have taken as $48.5 \mathrm{Rs} /$ litre and $38 \mathrm{Rs} / \mathrm{kg}$ respectively.

The energy saved by the PV based water pumping system is approximately $8516.67 \mathrm{kWh}$ and we by considering $40 \%$ transmission losses [11] whereas approximately 14194.45 $\mathrm{kWh}$ is the total power generated by the plant to accommodate these losses. Mittal et al. [12] described the Indian coal conditions and the pollutant thrown by the coal based power plants in western India in 2009-10 as: $\mathrm{CO}_{2}=$ $0.98 \mathrm{~kg} / \mathrm{kWh} \quad, \quad S O_{2}=1374.66 \mathrm{~g} / \mathrm{kWh} \quad, \quad \mathrm{NO}=$ $4.64 \mathrm{~g} / \mathrm{kWh}$.

The annual $\mathrm{CO}_{2}$ emission from the different fuels has been estimated with the help of a fuel analysis approach by North Carolina division of air quality [13].

$$
\begin{gathered}
\mathrm{CO}_{2} \text { emission }=\sum_{\mathrm{i}=1}^{\mathrm{n}} \mathrm{FC} \times \mathrm{HHV}_{\mathrm{fc}} \times \mathrm{CCC}_{\mathrm{fc}} \times \mathrm{OF}_{\mathrm{fc}} \times \\
\frac{\mathrm{MW}_{\mathrm{CO}}}{\mathrm{MW}_{\mathrm{c}}} \times \mathrm{C}
\end{gathered}
$$

Where, $F C=$ Fuel consumption in ton/year

$H H V_{f c}=$ High heat value in MMBtu/ton

$C C C_{f c}=$ Carbon content coefficient in kg-C/MMBtu

$O F_{f c}=$ Oxidation factor (1.00 for coal)

$M W_{f c}=$ Molecular weight of $\mathrm{CO}_{2}=44$

$M W_{c}=$ Molecular weight of carbon $=12$

$C=$ Conversion factor from $\mathrm{kg}$ to ton (1/907.2)

The lignite coal is assumed as fuel in power plants in Rajasthan state of India. Where all the values of high heat value, carbon content coefficient and oxidation factor selected from the table of above mentioned analysis. The specific coal consumption per $\mathrm{kWh}$ is taken as $0.77 \mathrm{~kg} / \mathrm{kWh}$ from Mittal et al. The discharge from the submersible pump is takes equivalent to the experimental value for all fuels.

\section{Result and Discussions}

The PV based water pumping system seems a promising option for energy conservation and it is helpful for reducing the $\mathrm{CO} 2$ emission. The total coal consumption is 10.93 tons during the year 2012 for production of $14194.45 \mathrm{kWh}$ electricity to accommodate the annual discharge of SVP based water pumping system. The annual $\mathrm{CO}_{2}$ emission is reduced by $14977.57 \mathrm{~kg} /$ year or 16.51 tons/year. These other pollutants are evaluated per $\mathrm{kWh}$ by Mittal et al. and total annual pollutants can be saved by, $\mathrm{SO}_{2}=11707.53 \mathrm{~kg} /$ year and $N O=39.52 \mathrm{~kg} /$ year. It is noted that the huge amount of carbon-di-oxide production can be reduced by using the PV based water pumping system and it is beneficial to reduce the global warming.

The NPV and PP values for different fuels are presented in table 1. The PV and PP of the PV based submersible pump is lies between the $\mathrm{CNG}$ and diesel system. $\mathrm{CNG}$ is not available every point of energy demand and diesel price is higher and it pollutes the environment. As per the environment, fuel price and fuel import concerned with the analysis there is only PV based water pumping system is found economical and most feasible solution.

Table 1. Economic indicators

\begin{tabular}{lll}
\hline Types of fuel system & NPV & PP \\
\hline CNG & 124787.79 & 3.787 \\
PV & 313860.63 & 1.814 \\
Diesel & 370155.60 & 1.354 \\
\hline
\end{tabular}

Table 2. Fuel replacement

\begin{tabular}{lllll}
\hline $\begin{array}{l}\text { Types of } \\
\text { fuel }\end{array}$ & $\begin{array}{l}\text { Calorific } \\
\text { value } \\
(\mathbf{M J} / \mathbf{k g})\end{array}$ & $\begin{array}{l}\text { Cost of } \\
\text { fuel } \\
\left({ }^{*} \mathbf{R s} / \mathbf{k g}\right)\end{array}$ & $\begin{array}{l}\text { Amount } \\
\text { of total } \\
\text { fuel }\end{array}$ & $\begin{array}{l}\text { Reduction } \\
\text { in CO2 }\end{array}$ \\
\hline & & & $\begin{array}{l}\text { saved } \\
\text { (Rs/year) }\end{array}$ & $\begin{array}{l}\text { emission } \\
(\mathrm{kg} / \text { year })\end{array}$ \\
& & & 106094.23 & 5775.026 \\
Diesel & 44.80 & 53.88 & 55416.92 & 3284.18 \\
CNG & 43.00 & 38.00 & & \\
\hline LPG & 160.00 & 85.00 & 123958.90 & 2428.14 \\
\hline
\end{tabular}

"Indian Rupees (Rs) and One USD = 54. 47 Indian rupees as dated on March 25, 2013[14] 


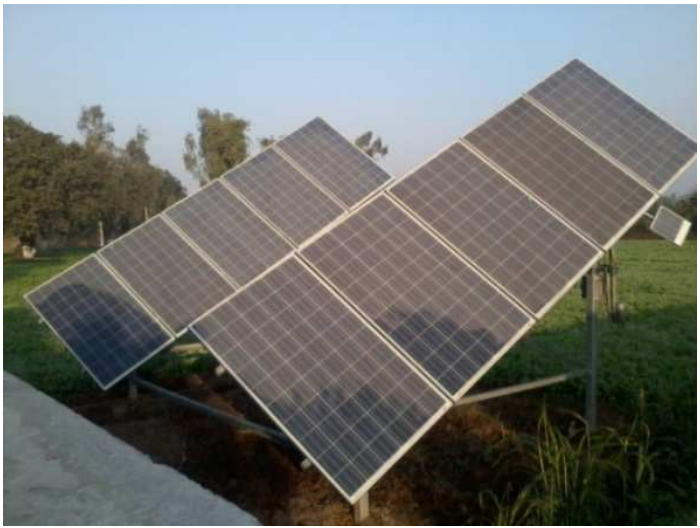

(a)

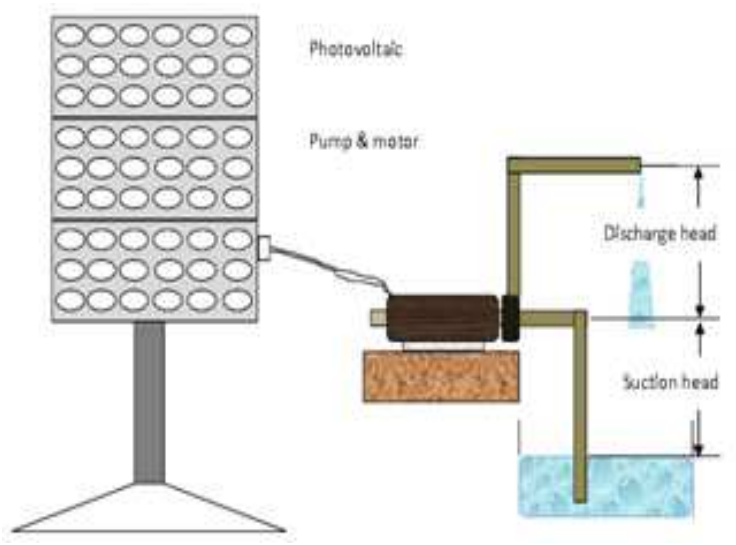

(b)

Figure 1. PV based water pumping system at Jasvinder farm house in Kota (a) Photo shot (b) Schematic view

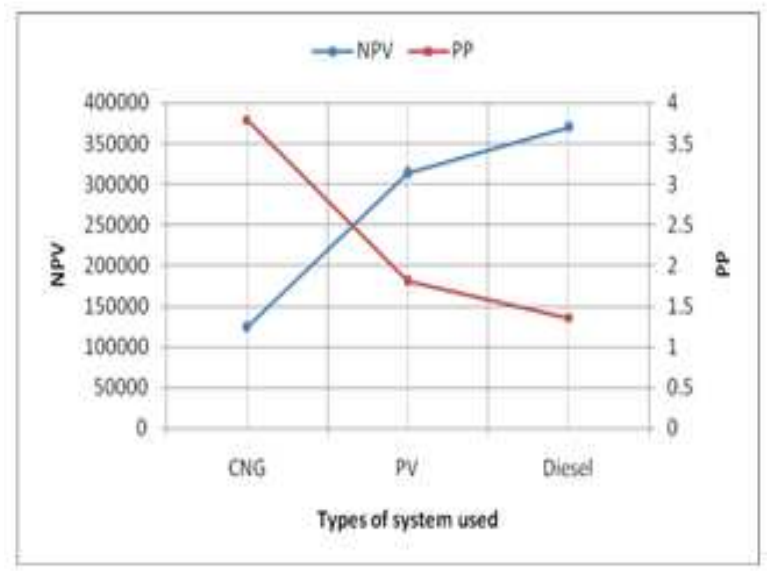

Figure 2. Relation between PV and PP for different fuels

\section{Conclusions}

The technology is not only reduces the GHG emissions but also help in fuel conservation. The PV based water pumping system is off-grid technology means it can be utilized where grid energy is not available. It is economically viable option only when government subsidy provided above $60 \%$, in this study costumer have pay for $85000 \mathrm{Rs}$ against the 405000.00Rs (Four lakh five thousand Rupees)[15] means costumer avail approximately $79 \%$ subsidy and the payback period is less than two years. This technology is also increasing the sustainability index. It can save money, time and environment of the world.

\section{Acknowledgements}

The author (Shiv lal) gratefully acknowledges Rajasthan Technical University, Kota (Rajasthan), India. The authors also grateful to RHDS and Udyan vibhag Rajasthan they installed the system at Jasvinder Singh farm house Kota.

\section{References}

[1] Akella A., Sharma M. and Saini R., "Optimum utilization of renewable energy sources in a remote area", Renewable and Sustainable Energy Reviews. Volume. 11 (5): 894-908 (June 2007).

[2] Brunicki, L.Y., "Sustainable energy for rural areas of the developing countries", Energy and Environment. 13: 515-522 (2002).

[3] Elliott, D., "Energy efficiency and renewable", Energy and Environment.15: 1099-1105 (2004).

[4] Panwar N.L., Kaushik S.C., Kothari S.C., "Role of renewable energy sources in environmental protection: a review", Renewable and Sustainable Energy Review 15: 1513-1524 (2011).

[5] Panwar N.L., Surendra K., Kaushik S.C., "Techno-economic evaluation of masonry type animal feed solar cooker", Energy policy, 52: 583-586 (2013).

[6] Aligah M Abu., "Design of Photovoltaic Water Pumping System and Compare it with Diesel Powered Pump", Jordan journal of mechanical and industrial engineering. 5 (3), 273-280 (2011).

[7] Hiremath R., Shikha S. and Ravindranath N., "Decentralized energy planning, modeling and application", Renewable \& sustainable energy review. 11 (5): pp. 729-752 (2007).

[8] Purohit P., "Financial evaluation of renewable energy technologies for irrigation water pumping in India", Energy policies, 353134-3144 (2007).

[9] Odeh I., Yohanis Y. G., \& Norton B., "Economic viability of a photovoltaic water pumping systems. Solar Energy, 80 (7): 850-860 (2012). doi:10.1016/j.solener.2005.05.008

[10] Kandpal T.C., Garg H.P., "Financial Evaluation of Renewable Energy Technology”, Macmillan India Ltd. 2003, Chapter27, pp. 293-306.

[11] http:/cleantechindia.wordpress.com/2008/07/16/indias-elect ricity-transmission-and-distribution-losses/(retrieve in January, 2013)

[12] Mittal M.L., Sharma C., Singh R., "Estimates of emissions from coal fired thermal power plants in India", International emission inventory conference, Tampa, Florida, August 14-16, 2012, pp. 1-22 
[13] North Carolina Division of Air Quality. Report on Greenhouse Gas Emission Guidelines: Stationary Combustion Sources. Available from: /http: //www. ncair.org/ monitor/eminv/forms/Stationary_Combustion_Sources. pdf's (retrieve on January, 2013).

[14] https://www.google.co.in/intl/en/help/currency_disclaimer.ht $\mathrm{ml}$ (retrieved on March 25, 2013)
[15] www.jainirrigation.com(retrieve in January, 2013)

[16] http://www.cea.nic.in/(retrieve in January, 2013)

[17] Rue du Can S. de la, McNeil M., and Sathaye J. India Energy Outlook: End Use Demand in India to 2020. LBNL, DOE California USA. ies.lbl.gov/iespubs/india_energy outlook. Pdf (retrieve on January, 2013) 